\title{
Households Waste Management Practices and Associated Factors in Tain District, Ghana
}

\author{
Bonaventure Bayor ${ }^{1}$, Edward W. Ansah ${ }^{1}$, Michael Afari Baidoo ${ }^{2 *}$ \\ ${ }^{1}$ Department of Health, Physical Education and Recreation (HPER), University of Cape Coast, Cape Coast. Ghana \\ ${ }^{2}$ Department of Health Administration and Education, University of Education, Winneba. Ghana \\ *Corresponding author email: baidoo.afari@yahoo.com
}

Received: 23 July 2021 / Accepted: 09 December 2021 / Published: 23 December 2021

\begin{abstract}
Objective: Rapid population growth has increased tons of waste generated daily in the various Ghanaian districts. A total of $9,331 \mathrm{~kg}$ of household waste is generated daily in the Tain District, but managing it becomes a challenge. The aim of the study was to investigate households' waste management practice in the Tain District of Ghana.

Method: A concurrent mixed method design was used to select four major communities in the Tain District for the study. A sampled of 1,037 female household heads were selected by convenient sampling for the qualitative and quantitative data collection. A questionnaire, participant and community observation were used to collect the data. Frequencies, percentages, logistic regression and observational interpretations were applied in analysing the data.

Results: Many gutters at homes were clogged, bushy environment and littering of home, and that, there were limited waste bins and containers available, and waste dumpsites were near community gathering places. Furthermore, the main household generated wastes included food scraps (41\%), but majority of the participants use public dumpsite $(76.37 \%)$ for waste disposal. Meanwhile, 825(8\%) of the households have high level of knowledge on the health effects of indiscriminate waste disposal. Conclusions: It is necessary to demarcate dumpsites away from community gathering places. The crude dumping places cannot contain the increase in waste production, which results in indiscriminate dumping of waste. Proper measures including regulations and standards are expected to be implemented for a more effective and efficient integrated waste management system in the district.
\end{abstract}

Keywords: Households, Solid waste, Waste management.

\section{Introduction}

Sanitation is a critical for human dignity, health and development issue. Waste management constitutes one of the most crucial health, environmental, and developmental challenges for all cities and communities (Baabereyir, 2009). Therefore, waste management becomes an inevitable aspect of life (McAllister, 2015). Household waste are materials generated from homes and identified as no longer being of value and are either thrown away or gathered for disposal (Momoh \& Oladebeye, 2010). The main components of household waste are food debris, plastics, used clothing, and plastic packaging (Asante, 2016), all of which can create both human and environmental health challenges if not managed properly (Denteh et al., 2018; Miezah et al., 2014).

Due to rapid urbanization and population growth, the total household waste generated in the Tain District has increased steadily over the past years, from 7,667kg of waste in 2010 to 9,331 kg in 2018 (Miezah et al., 2014). This increase in waste exerts obvious consequences on the environment, public health and waste management system (Bekoe-Nketia, 2015). It is estimated that 84,200 people die each year from diseases such as cholera and typhoid as a result of human waste through contamination (Melnick, McNeely, \& Navarro, 2005). Effective waste management strategies need to scale up to protect the environment and 
public health. Several researchers attempted to understand the factors accounting for improper waste management in Ghana (Asante, 2016; Yoada et al., 2014). However, many of these researchers have focused on only solid waste management in urban towns (Pussadee et al., 2017; Denteh et al., 2018). This article investigates household waste management practice in the Tain District. The results, findings and conclusions from this study may inform Zoomlion and Tain District Environmental Health and Management Officers so that proper waste management strategies can be scaled up to improve sanitation situation in the Tain District.

\section{Methods}

This mixed method study took place in four rural communities; Debibi, Seikwa, Nsawkaw and Badu, within the Tain District. Consenting female household heads numbering 1,037 were sampled for the study. These women are believed to be the main generators and users and managers of domestic waste materials in their households (Nyatsanza \& Ndebele, 2016). The quantitative aspect of the study solicited information on household waste management practices, while the qualitative aspect employed observation to describe the waste management situation at the various households. Data collection begun on $3^{\text {rd }}$ January and ended on $29^{\text {th }}$ January 2019.

The study was conducted at the homes of the participants. The four communities were selected using simple random sample method, whereby out of the 12 notable communities, the first-four randomly selected ones were chosen. We employed four undergraduate students who did the picking. These students did not know what they were picking the papers which were folded and placed in the bowls. In addition, we systematically selected the households and their women heads for the study. Thus, at each community, we selected the first house, followed by the next third-house, and the next third house from the immediately selected one. This was carried out both at the right and left sides of each community. In each house, we looked for the number of households and collected data from the woman head if the house contained only a household. However, if there were two households, we collected data from only one head, selected randomly, but where the households were three or more, we selected two heads by random.

A few of the women household heads could read and write in the English language. These participants were given the questionnaire to fill on their own. However, we employed interviewadministered format in collecting the data from others who could not read and understand English language (Blanche et al., 2006; Quartey \& Awoyemi, 2002). Furthermore, participants were assured of their anonymity, confidentiality and voluntary participation and were explained to that they could withdraw from the study at any point in time without a consequence. Moreover, each participant gave verbal or written consent before taking part in the study. We were also granted ethical clearance by the Institutional Review Board of the University of Cape Coast (UCCIRB/CE/2019/07) to conduct the study. Besides, we sought and obtained authorization from Chiefs, Assembly Men of the communities and District Chief Executive of the district. No incentives were given to participants.

\subsection{Measures}

We utilized a questionnaire and an observation check list to collect data for the study. The items for the instruments were derived from the literature in accordance with the purpose of the study. The questionnaire was structured in two parts; A and B. Part A collected participants' demographic information such as age, gender, education and monthly income (5 items). Part two of the questionnaire included 24 items which solicited information on household waste management practices. This aspect of the questionnaire collected information on places of waste disposal and satisfaction with waste the services provided by the management institutions in the district. In addition, the observation checklist collected information such as whether there were visible untheorized dumping sites close to homes, the state of gutters around homes, receptacles, etc. We submitted these instruments to experts in Environmental Sanitation and Health Promotion who scrutinized the items to improve the validity. To ensure validity and 
Bayor et al., Adv. J Social Sci.; Vol. 9, Issue 1, pp: 36-42, 2021

reliability of the study, pre-testing was embarked using ten respondents from Banda Boase Community (Ogah, 2013).

\subsection{Data Analysis}

The data was entered into Statistical Product for Service Solutions software (SPSS Version 21.0 for Windows) for analysis. The analyses were carried using descriptive and inferential statistics. We used frequency and percentage counts to present participants' socio-demographic information. Meanwhile, logistic regression was calculated to determine resident's levels of knowledge and waste management practices.

\section{Results}

The mean age of the participants was 42 years. The family size for the households included in the survey ranged from 3 to $15(\mathrm{M}=6.41)$ people. The results further indicated that food scraps accounted for abundant of waste generated, 425(41\%), followed by plastics waste, 340(32.7\%), packaging materials, $82(8.0 \%)$, and the least was used clothes, 11(1.1\%) (See figure 1, appendix 1). Moreover, the main waste disposal place used in Tain District is public dumpsites accounting for $76.37 \%$ of places used as dumping sites (See Table 1). Furthermore, the data revealed that 519(50.05\%) of the participants were dissatisfied with the work of waste management institutions in the district.

Table 1: Frequency and percentage of participants' demographics, places of waste disposal and their satisfaction with the work of waste management companies

\begin{tabular}{lll}
\hline Variables & Frequency & Percentage \\
\hline Demographics & & \\
\hline Education & 326 & 31.44 \\
No formal education & 207 & 19.95 \\
Primary level education & 335 & 32.30 \\
Elementary level education & 124 & 4.96 \\
Secondary level education & 45 & \\
Tertiary level education & & 55.26 \\
\hline Occupation & 573 & 28.93 \\
\hline Farmers & 300 & 9.84 \\
\hline Traders & 102 & 5.98 \\
\hline Public sector workers & 62 & \\
\hline Others & & 76.18 \\
\hline Income level (GHC) & 790 & 17.10 \\
\hline Less than 500 & 177 & 6.72 \\
\hline 500-1,000 & 70 & \\
More than 1,000 & & 3.47 \\
\hline Place of disposal & 36 & 2.03 \\
Roadside & 21 & 3.18 \\
Nearby gutter & 33 & 12.44 \\
Skip & 129 & 76.37 \\
Backyard & 792 & 1.25 \\
Dump sites & 13 & 1.25 \\
Open spaces & 13 & 11.67 \\
Other, specify & & 38.28 \\
Level of Satisfaction & 121 & 42.24 \\
Very satisfy & 397 & 7.81 \\
Satisfy & 438 & \\
Unsatisfactory & 81 & \\
Very unsatisfactory & & \\
\hline
\end{tabular}




\subsection{Factors influencing indiscriminate waste disposal practices}

The aim of this analysis was to determine the variables that could predict the odds of indiscriminate waste disposal practices in the Tain District. Knowledge independently and significantly predicts waste management practices; $p=0.001, \mathrm{OR}=1.19$ (See Table 2).

Although waste generation is increasing steadily in the Tain District, insufficient resources for waste management are the main challenges confronting waste management sector in the Tain District. Provision of waste collection containers and bins be the first strategy and outline by participants to be implemented to managed household waste. In addition, close to $80 \%$ (825) of the participants were aware that improper waste management contributes to disease causation; most of the respondents thought that improper waste management could lead to malaria and diarrhoea. On environmental health, most participants agree that improper disposal of waste contribute to clogging of drains, unsightness and pollution of waste bodies.

Table 2: Factors influencing indiscriminate waste disposal practices among households in Tain District

\begin{tabular}{llllll}
\hline Variable & Wald & $\boldsymbol{d f}$ & Sig. & $\boldsymbol{O R}$ & $\mathbf{9 5 \%} \boldsymbol{C I}$ \\
\hline Knowledge on waste disposal practices & 6.28 & 1 & 0.001 & 1.19 & $1.13-1.25$ \\
Age & 1.42 & 1 & 0.155 & 1.01 & $1.00-1.02$ \\
Education & & & & & \\
None & Ref & & & & \\
Primary & -2.33 & 1 & 0.020 & 0.54 & $0.32-0.91$ \\
Elementary & -1.98 & 1 & 0.048 & 0.63 & $0.40-1.00$ \\
Secondary & -0.86 & 1 & 0.388 & 0.76 & $0.41-1.42$ \\
Tertiary & -0.81 & 1 & 0.415 & 0.76 & $0.40-1.47$ \\
Household size & & & & & \\
$\quad$ 1-5 & Ref & & & & \\
$\quad$ 6-10 & 1.95 & 1 & 0.052 & 0.70 & $0.49-1.00$ \\
$\quad 11+$ & 0.18 & 1 & 0.855 & 1.06 & $0.58-1.93$ \\
\hline
\end{tabular}

The observational data suggested a need for households to improve the waste management practices in the Tain District. From the data, it was observed that many of the receptables in the various households were not covered, in-and-around the houses were littered, no waste separation, environments of many households were bushy and gutters chocked (See Table 3).

Table 3. Observational study

\begin{tabular}{lll}
\hline \multicolumn{1}{c}{ CONTENT } & YES (\%) & NO (\%) \\
\hline The house areas are free of visible garbage & $689(67.02)$ & $339(32.98)$ \\
Is there receptacle for waste in the house & $925(89.98)$ & $103(10.02)$ \\
The waste receptacle in the house has a tight-fitting lid & $346(33.66)$ & $682(66.34)$ \\
The waste disposal areas are away from water source & $618(68.97)$ & $278(31.03)$ \\
There is littering of the house environment. & $307(34.26)$ & $589(65.74)$ \\
There is waste separation done at the house & $241(23.44)$ & $787(76.56)$ \\
The house and surroundings are bushy & $358(34.82)$ & $670(65.18)$ \\
Gutters at homes are chocked & $347(33.79)$ & $680(66.21)$ \\
\hline
\end{tabular}

\section{Discussions}

The aim of the study was to investigate household waste management practices and some factors influencing such practices among households in Tain District. The finding indicated that food scraps accounted for abundant of waste generated. Perhaps, because predominantly the people of Tain are farmers. However, leaving food debris unattended to has the potential of serving as breeding grounds for rodents 
and insects that could increase the spread of parasitic and zoonotic diseases such a malaria, cholera, and worm infestation (Abeyewickreme et al., 2012). Therefore, appropriate disposal and management of these household waste is essential, but it is also based on the type of waste generated in the community (Yusof $e t$ al., 2002).

Availability of place of waste disposal has long been recognized as crucial factor in influencing household waste disposal practices (Nixon \& Saphores, 2009). The main waste disposal site used in the district is public dumpsites, crude dumping. Meanwhile, it was also found that many at the households use the crudely dump their waste at other unauthorized places especially in the nearby bushes (Dhanuja's, 2006; Aderemi \& Falade, 2012). These improper waste disposal practices have the propensity to spread diseases to human health and present unhealthy esthetic environment (Adu-Boahen et al. 2014). Thus, these is the need to involve waste management companies in the management of community waste.

The findings further showed that the waste management services provided by the companies and agencies such as Zoomlion Company and the Environmental Health Management Department were unsatisfactory to the households (Burntley, 2007, Yoada et al. 2014). This could be because of the poor quality of waste collection and disposal services rendered to the community members in the district (Manga, Forton \& Read, 2008). For instance, participants expected that these institutions will provide sufficient number of waste collection containers and bins and empty such on time. This they believed could be the first strategy to implementing properly, the household waste management in the communities. Thus, the non-availability of such waste collection equipment resorted to dumping waste at dumps sites and other open spaces (Cointreau, 2006, Puopiel \& Owusu-Ansah, 2014).

We also observed that women household heads with high amount of waste management knowledge were more likely to practice "better" waste management in their homes (Sisay, 2017, Haile, 2011). Evidence shows that knowledge is a major barrier or asset in participation in waste management activities such as separation of waste at source, and community members who are better educated would have a greater chance of participating in such waste management practices than less educated members (Xiao, Zhang, Zhu, \& Lin, 2017). Therefore, awareness creation campaigns are key to changing the attitudes of community members towards better waste management practices (Babazadeh, Nadrian, Mosaferi, \& Allahverdipour, 2018; Chu, Xi, Song \& Crampton, 2013). Awareness campaigns can be done through newspapers, internet, community meetings, 314 radios and television.

Again, the study revealed that close to $80 \%$ of the participants were aware that improper waste management contributes to disease causation; most of the respondents thought that improper waste management could lead to malaria and diarrhoea. On environmental health, most participants agree that improper disposal of waste contribute to clogging of drains, and pollution of waste bodies (Okechukwu et al., 2012, Sujayita, 2018). Accordingly, there was a great need for households to improve their waste management practices in the Tain District. Thus, the observation revealed that there were negative responses associated with waste management issues in the Tain District (Adeyemo, 2013, Obiageli, 2016, Adepoju \& Salimonu, 2010). Also, close surroundings of the majority of the houses visited were bushy, no waste separation done, no tight covering of lid for receptacle for storing waste. Gutters at community were clogged with open burning. These practices are unhealthy and poses health danger to the community members especially children.

\section{Conclusion}

The population growth in Tain District have increased household waste generation which included predominantly perishable food waste. The main waste disposal place used in Tain District is public dumpsite. However, many of the households practice crude dumping where they dump at the public dumping site, a place which cannot contain the increase waste production in the various communities in the district. It is observed that as the environmental sanitation knowledge of the female household heads increases, there likelihood of practicing proper waste management also increases. Therefore, environmental sanitation education is needed especially to the female household heads who are day-to-day managers of 
the household waste in the rural communities. The waste management activities of the waste collection institutions in the district also lack commendation from the female household heads. Thus, these institutions and agencies need to be encouraged to up their waste management activities. It is necessary to construct more landfill sites and a distance away from the communities.

\section{Declarations}

\subsection{Acknowledgements}

We thank the Chiefs and Opinion leaders of the communities, the District Chief Executive and the women who spent their time and energy responding to our instruments.

\subsection{Competing Interests}

Authors declare that they have no competing interest.

\section{How to Cite this Article:}

Bayor, B., Ansah, E. W., \& Baidoo, M. A. (2021). Households Waste Management Practices and Associated Factors in Tain District, Ghana. Advanced Journal of Social Science, 9(1), 36-42. https://doi.org/10.21467/ajss.9.1.36-42

\section{References}

Abeyewickreme, W., Wickremasinghe, A. R., Karunatilake, K., Sommerfeld, J., \& Axel, K (2012). Community mobilization and household level waste management for dengue vector control in Gampaha District of Sri Lanka; An intervention study. Pathogens Global Health, 106(8), 479-487.

Aderemi, A. O., \& Falade, T. C. (2012). Environmental and health concerns associated with the open dumping of municipal solid waste: A Lagos, Nigeria experience. American Journal of Environmental Engineering, 2(6), 160-165.

Adu-Boahen, K., Atampugre, G., Antwi, K. B., Osman, A., Osei, K. N., Mensah, E. A., \& Adu-Boahen, A. O. (2014). Waste management practices in Ghana: Challenges and prospect, Jukwa Central Region. International Journal of Development and Sustainability, 3(3), 530-546.

Asante, J. (2016). Assessment of household solid waste management practices in the Sunyani West District. Dissertation submitted to the University of Ghana. Unpublished master's dissertation.

Baabereyir, A. (2015). Urban environmental problems in Ghana: A case study of social and environmental injustice in solid waste management in Accra and Sekondi-Takoradi. Norway: University of Nottingham.

Babazadeh, T., Nadrian, H., Mosaferi, M., \& Allahverdipour, H. (2018). Identifying challenges and barriers to participating in the source separation of waste program in Tabriz, Northwest of Iran: A qualitative study from the citizens' perspective. Resources, 7, 53.

Burntley, S. J. (2007). A review of municipal solid waste composition in the United Kingdom. Journal of Waste Management, 27(10), 12741285.

Chu, Z., Xi, B., Song, Y., \& Crampton, E. (2013). Taking out the trash: Household preferences over municipal solid waste collection in Harbin, China. Habitat Int., 40, 194-200.

Cointreau, S. (2006). Occupational and environmental health issues of solid waste management. Special emphasis on middle- and lowerincome counties. World Bank: Urban Papers.

Denteh, S. N., Cobbina, S. J., Adam, W., \& Aboka, E.Y. (2018). Household solid waste management: Compositional analysis, storage and collection in the Vittin Target Area, Tamale-Ghana. UDS International Journal of Development, 5(2), 105-116.

Dhamija, U. (2006). Sustainable solid waste management. New Delhi: Sage Publication.

Manga, V. E., Forton, O. T., \& Read, A. D. (2008). Waste management in Cameroon: A new policy perspective. Resources, Conservation and Recycling, 52(4), 592-600.

McAllister, J. (2015). Factors influencing solid-waste management in the developing world. Canada: Utah University State.

Melnick, D., McNeely, J., \& Navarro, Y. K. (2005). Environment and human well-being: A practical strategy. London: Earthscan.

Miezah, K., Obiri-Danso, K., Kádár, Z., Fei-Baffoe, B., \& Mensah, M. Y. (2015). Municipal solid waste characterization and quantification as a measure towards effective waste management in Ghana. Waste Management, 46(1), 15-27.

Momoh, J. J., \& Oladebeye, D. H. (2010). Assessment of awareness, attitude and willingness of people to participate in household solid waste recycling programme in Ado-Ekiti, Nigeria, Jakarta Indonesia. Journal of Applied Sciences in Environmental Sanitation, 5(1), 93-105.

Nixon, H., \& Saphores, J. D. M. (2009). Information and the decision to recycle: Results from a survey of US households. Journal of Environmental Planning and Management, 52(2), 257-277.

Nyatsanza, T. D, \& Ndebele, S. K. (2016). The usefulness of including women in household solid waste management. A case study of dzivaresekwa high density suburb; Harare. IOSR Journal of Humanities and Social Science, 21(3), 92-108.

Ogah, J. K. (2013). Decision making in the research process: Companion to students and beginning researchers. Accra: Adwinsa Publication.

Okechukwu, O. I, Okechukwu, A. A., Noye-Nortey, H., \& Owusu-Agyei (2012). Health perception of indiscriminate waste disposal - A Ghanaian case study. Journal of Medicine and Medical Sciences, 3(3), 146-154.

Puopiel, F., \& Owusu-Ansah, J. (2014). Solid waste management in Ghana: The case of Tamale Metropolitan Area. Journal of Environment and Earth Science, 4(17), 2224-3216.

Pussadee, L., Yanasinee, S., Vivat, K., Anuttara, H., Tawatchai, A., \& Nittaya, P. (2018). Knowledge, Attitude and Practice of municipal solid waste management among highland residents in Northern Thailand. Journal of Health Research, 32(2), 123-131. 
Singh, A., \& Sharma, S. (2002). Composting of a crop residue through treatment with microorganisms and subsequent vermicomposting. Bioresource Technology, 85(2), 107-111.

Sisay, S., Tariku, D., Hawi, A., Nardos, T., \& Tesfaye, A. (2017). Assessment of knowledge attitude and practice towards solid and liquid waste management among Addis and Kometa Kebele Community Mizan, Ethiopia. Biomedical Journal of Science and Technical Research, 1(15), 1-9.

Sujayita, B (2018). 'Where goes the waste?' A knowledge, attitude, and practice study on disposal of household waste. Open access international journal of science and engineering, 3(1), 25-29.

Xiao, L., Zhang, G., Zhu, Y., \& Lin, T. (2017). Promoting public participation in household waste management: A survey-based method and case study in Xiamen city, China. J. Clean Prod., 144, 313-322.

Yoada R. M, Chirawurah, D., \& Adongo P. B. (2014). Domestic waste disposal practice and perceptions of private sector waste management in urban Accra. BMC Public Health, 214, 697.

Yusof, M. B. M., Othman, F., Nashim, N., \& Nur, C. A. (2002). The role of socio-economic and cultural factors in municipal solid waste generation: A case study in Taman Berling, Johor Bahru. J Teknologi, 37, 55-64.

\section{Appendix 1}

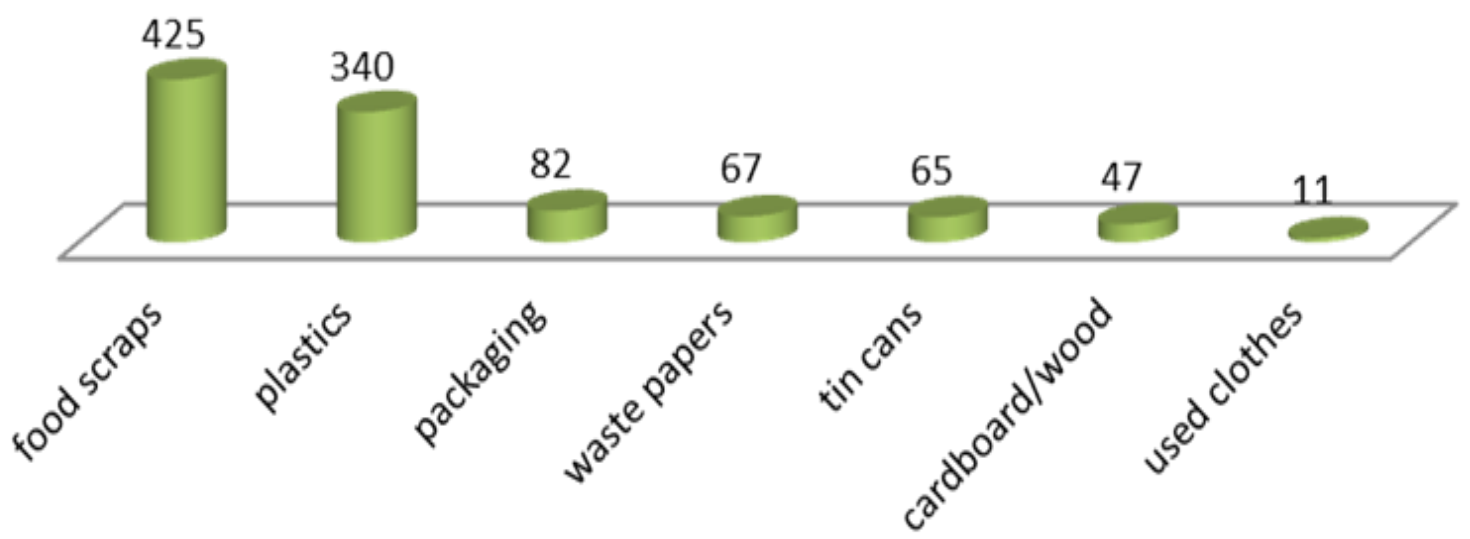

Source: Field survey, Bayor (2018)

Figure 1: Distribution of types of waste generated in Tain District

Publish your research article in AIJR journals-

- $\quad$ Online Submission and Tracking

- $\quad$ Peer-Reviewed

- $\quad$ Rapid decision

- Immediate Publication after acceptance

- Articles freely available online

- Retain full copyright of your article.

Submit your article at journals.aijr.org
Publish your books with AIJR publisher-

- $\quad$ Publish with ISBN and DOI

- Publish Thesis/Dissertation as Monograph.

- Publish Book Monograph.

- Publish Edited Volume/ Book.

- Publish Conference Proceedings

- Retain full copyright of your books.

Submit your manuscript at books.aijr.org 